Vol 12, Issue 12, 2019

\title{
PHYTOCHEMICAL AND ANTIOXIDANT ACTIVITY OF BALIOSPERMUM MONTANUM (WILLD.) MUELL. ARG.
}

\section{RAVEESHA HR*, SUSHMA BK}

Department of Botany, Bangalore University, Jnana Bharathi Campus, Bengaluru, Karnataka, India. Email: hrraveesh74@gmail.com Received: 30 August 2019, Revised and Accepted: 01 October 2019

\section{ABSTRACT}

Objective: The present study was carried out to evaluate the phytochemical constituents and antioxidant potential of the leaf, stem, root, and stemderived callus extracts of Baliospermum montanum.

Methods: An in vitro regeneration protocol was developed for the induction of callus from stem segments cultured on Murashige and Skoog(MS) medium supplemented with different concentrations and combination of 6-benzylaminopurine (BAP), 6-furfurylaminopurine (KIN), 1-naphthaleneacetic acid, and 2, 4-dichlorophenoxyacetic acid. The total phenol, flavonoid, and tannin content were determined according to standard methods. The antioxidant activity of methanolic extract was evaluated using 2, 2-diphenyl-l-picrylhydrazyl (DPPH) and reducing power assays.

Results: The maximum callus induction was observed on MS medium supplemented with a combination of KIN (0.5 mg/L) + BAP (3.0 mg/L). Methanolic extract of root and aqueous extract of leaf exhibited higher content of phenols. Whereas total flavonoids and tannin were maximum in methanolic extract of leaf compared to other extracts. The methanolic extract of B. montanum leaf had greater antioxidant activity than stem, root, and callus by DPPH and reducing power assays.

Conclusion: Our study suggests that the methanolic extracts of $B$. montanum showed potent free radical scavenging activity. Further studies are necessary for isolation and characterization of phytochemical compounds.

Keywords: Baliospermum montanum, Callus induction, 2, 2-diphenyl-l-picrylhydrazyl, Reducing power assay.

(C) 2019 The Authors. Published by Innovare Academic Sciences Pvt Ltd. This is an open access article under the CC BY license (http://creativecommons. org/licenses/by/4. 0/) DOI: http://dx.doi.org/10.22159/ajpcr.2019.v12i12.35534

\section{INTRODUCTION}

Plants have formed the basis of traditional medicine systems that have been in existence for thousands of years. Even in modern times, plantbased systems continue to play an essential role in health care. It has been estimated by the World Health Organization that approximately $80 \%$ of the world's population from developing countries rely mainly on traditional medicines (mostly derived from plants) for their primary health care [1]. The plant-based chemical compounds are classified into two classes; primary and secondary metabolites based on their chemical, biosynthetic origin, and functional groups. Primary metabolites are involved in growth and development, and secondary metabolites are in defense mechanism against harmful pests and infectious agents. Plant derived chemicals such as terpenoids, phenolics, alkaloids, flavonoids, glycosides, diterpenes, triterpenes etc., which shows better compatibility with the human body to resist against harmful diseases [2].

Most of the aromatic and medicinal plants contain chemical compounds with antioxidant properties. Several studies carried out on medicinal plants led to the development of natural antioxidant formulations for food, cosmetic, and other applications [3]. There is an increasing interest in natural antioxidants, for example, polyphenols present in medicinal and dietary plants, which might help to prevent oxidative damage. Naturally occurring antioxidants increase the antioxidant capacity of the plasma and reduce the risk of disease [4]. At present, keen interests and widespread researches on exogenous antioxidants from natural sources perhaps, due to the fact that they are less expensive, readily available and believed to have lesser side effects when compared to their synthetic counterparts [5].

Baliospermum montanum is commonly known as Danti, which belongs to the family Euphorbiaceae. It is found in tropical and subtropical Himalayas from Kashmir eastwards to Arunachal Pradesh. Root, leaf, and seeds of the plants are used medicinally. The root contains phorbol ester belonging to diterpene hydrocarbon, namely, montanin, baliospermin, 12-deoxyphorbal-13-palmitate, 12-deoxy-5 $\beta$-hydroxyphorbal-13myristate, and 12-deoxy-16-hydroxyphorbol 13-palmitate. Leaves contain $\beta$-sitosterol, $\beta$-D-glucoside, and hexacosanol. Steroids, terpenoids, and flavonoids are also reported in this plant [6]. The root is acrid, thermogenic, purgative, antihelminthic, carminative, and antiinflammatory. Seeds, roots, and leaves are used to treat abdominal pain, constipation, calculus, piles, helminthic manifestations, skin disorders, wound, jaundice, asthma, bronchitis, and also used in snakebite $[7,8]$. Thus, the aim of this study was to evaluate the phytochemical and antioxidant activity of methanol, aqueous, and chloroform extracts of B. montanum leaf, stem, root, and stem-derived callus.

\section{METHODS}

Collection and sterilization of seeds

B. montanum and seedlings collected from wild plants grown in Western Ghats (Karnataka), India. The plant material was authenticated at the Botanical Survey of India, Western Regional Centre, Pune, and the voucher specimen was deposited in the No. BSI/WRC/100-1/IDEN. CER./018/77. The seeds will be washed thoroughly under running tap water for $20 \mathrm{~min}$ and rinsed with Teepol solution $5 \%(\mathrm{v} / \mathrm{v})$ and washing with sterile double distilled water 3-4 times and the sterilized seeds will be transferred to nursery trays, then pots containing a mixture of sterile soil, sand, and manure (2:1:1) and maintained in the greenhouse condition.

\section{Callus induction}

Nodal explants were sterilized with different sterilants (Teepol and bavistin), followed by $0.1 \% \mathrm{HgCl}_{2}$ for 2 min under aseptic condition and then washed with sterile water for 3-5 times to remove the traces of sterilants. Finally, sterilized explants were cultured on Murashige and Skoog (MS) medium supplemented with different concentrations and 
combination of 6-benzylaminopurine (BAP), 6-furfurylaminopurine (KIN), 1-naphthaleneacetic acid (NAA), and 2, 4-dichlorophenoxyacetic acid $(2,4-D)$. Cultures were incubated at $25 \pm 2^{\circ} \mathrm{C}$ in a culture room with $70-80 \%$ relative humidity and $16 \mathrm{~h}$ of photoperiod.

\section{Preparation of extracts}

The extracts were prepared according to the procedure of Samydurai and Saradha [9]. Briefly, $10 \mathrm{~g}$ of dried leaf, stem, root, and stem-derived callus were finely powdered using blender and extracted with $100 \mathrm{ml}$ of different solvents (methanol, aqueous, and chloroform) for $24 \mathrm{~h}$. Then, the extracts were concentrated by evaporation. The dried extract was stored at $4^{\circ} \mathrm{C}$ until further analysis.

\section{Determination of total phenolics content (TPC)}

The TPC of methanol, aqueous, and chloroform extracts was determined by Folin-Ciocalteu method [10] with slight modification, using gallic acid as standard. $0.5 \mathrm{ml}$ of various solvent extracts was mixed with $0.5 \mathrm{ml}$ of FC reagent and allowed to stand for $5 \mathrm{~min}$ at room temperature to allow complete reaction with FC reagent. $1 \mathrm{ml}$ of $7 \%$ sodium carbonate was added and the final volume was made up to $5 \mathrm{ml}$ using distilled water. The absorbance of blue color solution was measured at $725 \mathrm{~nm}$ using ultraviolet (UV)-visible spectrometer against the blank after the incubation of $90 \mathrm{~min}$ in dark. The experiments were carried out in triplicates. A calibration curve was prepared using standard solution to obtain the readings within the range of 5-50 $\mu \mathrm{g}$ gallic acid $/ \mathrm{ml}$. The total phenolics compounds were expressed as mg of gallic acid equivalents (mg GAE/g) of extract.

\section{Determination of total flavonoids}

The total flavonoids content in leaf, stem, root, and stem-derived callus extracts was estimated by modified aluminum chloride method [11]. $0.5 \mathrm{ml}$ of samples were mixed with $2 \mathrm{ml}$ of $95 \%$ methanol, $0.1 \mathrm{ml}$ of $10 \%$ aluminum chloride, and $0.1 \mathrm{ml}$ of $1 \mathrm{M}$ potassium acetate and final volume was made up to $6 \mathrm{ml}$ by adding distilled water. After incubation at room temperature for $30 \mathrm{~min}$, the absorbance of the reaction mixture was measured at $415 \mathrm{~nm}$ with UV-visible spectrometer against the blank. The experiments were carried out in triplicates. The final absorbance of each sample was compared with a standard curve plotted from quercetin. The total flavonoids content was expressed in $\mathrm{mg}$ of quercetin equivalents per gram of extract (mg QE/g).

\section{Estimation of tannins}

Total tannins were determined according to the procedure of Medini et al. [12]. Briefly, to $0.5 \mathrm{ml}$ of samples, $3 \mathrm{ml}$ of $4 \%$ vanillin solution in methanol and $1.0 \mathrm{ml}$ of concentrated hydrochloric acid were added. The mixture was then shaken and incubated at room temperature (RT) for $15 \mathrm{~min}$; the absorbance was measured at $500 \mathrm{~nm}$ against blank. The experiments were carried out in triplicates. The final absorbance of each sample was compared with a standard catechin. The total tannin content was expressed in $\mathrm{mg}$ of catechin equivalents per gram of extract (mg CE/g).

Determination of 2, 2-diphenyl-l-picrylhydrazyl (DPPH) radicals scavenging activity

Free radical scavenging activity was studied using 1-1-diphenyl-2picrylhydrzyl according to Shoib and Shahid [13]. Different aliquots of leaf, stem, root, and stem-derived callus extracts $(20-100 \mu \mathrm{g} / \mathrm{ml})$ were mixed with $3 \mathrm{ml}$ of $0.25 \mathrm{mM}$ of methanolic solution of DPPH. Incubate the reaction mixture at room temperature for $30 \mathrm{~min}$ in dark condition. The absorbance was measured at $517 \mathrm{~nm}$ using UV-visible spectrometer. Butylated hydroxytoluene (BHT) was used as standard. All estimations were performed in triplicate. The DPPH radical scavenging activity was calculated using the following equation:

$$
\% \text { of inhibition }=\frac{\text { Absorbance of control }- \text { Absorbance of sample }}{\text { Absorbance of } \operatorname{control}} \times 100
$$

\section{Reducing power assay}

The reducing power assay was done according to the protocol of Kuda et al. [14] with minor modifications. Different concentrations of root, stem, leaf, and callus extracts $(20-100 \mu \mathrm{g} / \mathrm{ml})$ were mixed with $2 \mathrm{ml}$ of phosphate buffer $(0.1 \mathrm{M} \mathrm{pH} 7)$ and $2 \mathrm{ml}$ of $1 \%$ potassium ferricyanide. The mixture was incubated at $50^{\circ} \mathrm{C}$ for $20 \mathrm{~min}$ and kept at RT, then add $2 \mathrm{ml}$ of $10 \%$ trichloroacetic acid. The mixture was centrifuged at $3000 \mathrm{rpm}$ for $10 \mathrm{~min}$. Finally, $1 \mathrm{ml}$ of sample was mixed with same volume of d.w and $0.5 \mathrm{ml}$ of ferric chloride solution $(0.1 \%)$. The absorbance was measured at $700 \mathrm{~nm}$. Ascorbic acid was used as a standard.

\section{Statistical analysis}

The results were expressed as mean \pm standard deviation (SD). All the experiments were repeated thrice, and data were analyzed by one-way analysis of variance followed by Duncan's multiple range tests using SPSS software. $p<0.05$ was considered statistically significant.

\section{RESULTS AND DISCUSSION}

\section{Callus induction}

Stem explants were inoculated on MS medium supplemented with different concentrations of auxins and cytokinins (Table 1). Among the various concentrations and combinations, maximum creamish compact callus was achieved on MS medium supplemented with $0.5 \mathrm{mg} / \mathrm{L}$ of $\mathrm{KIN}+3.0 \mathrm{mg} / \mathrm{L}$ of BAP $(17.33 \pm 1.15)$ and green semi-friable callus was recorded in $0.5 \mathrm{mg} / \mathrm{L}$ of BAP $+0.5 \mathrm{mg} / \mathrm{L}$ of NAA $(16.80 \pm 0.34)$ compared to other concentrations (Fig. 1). The previous studies also reported that maximum callus induction was observed in combination of NAA $(4.0 \mathrm{mg} / \mathrm{L})+\mathrm{BAP}(0.5 \mathrm{mg} / \mathrm{L})$ from intermodal region of Orthosiphon stamineus [15]. Studies by Nathar and Yatoo [16] noticed highest callus induction on combination of 2, 4-D $(2.0 \mathrm{mg} / \mathrm{L})+\mathrm{KIN}(1.0 \mathrm{mg} / \mathrm{L})$ from the Artemisia pallens shoot tip region compared to other concentrations and combination of growth hormones.

\section{Total phenolic content}

Phenolic compounds are ubiquitous secondary metabolites in plants. They have multiple biological effects such as prevention of platelet aggregation and damage of red blood cells $[17,18]$. They play an important role in absorbing and neutralizing free radicals, quenching singlet and triplet oxygen, or decomposing peroxides [19]. The results were determined using the linear regression equation $(\mathrm{y}=0.058 \mathrm{x}$

Table 1: Effect of auxins and cytokinins on callus induction from stem explants of Baliospermum montanum

\begin{tabular}{|c|c|c|c|c|}
\hline Growth hormones & $\begin{array}{l}\text { Concentration } \\
\text { (mg/L) }\end{array}$ & $\begin{array}{l}\text { Number of } \\
\text { explants }\end{array}$ & $\begin{array}{l}\text { Number of explants } \\
\text { responded }\end{array}$ & Nature of callus \\
\hline \multirow[t]{3}{*}{$\mathrm{BAP}+\mathrm{NAA}$} & $0.5+0.5$ & 20 & $16.80 \pm 0.34^{\mathrm{de}}$ & Green semi-friable callus \\
\hline & $0.5+1.0$ & 20 & $15.60 \pm 1.21^{\text {cde }}$ & Green semi-friable callus \\
\hline & $3.0+1.0$ & 20 & $13.66 \pm 2.08^{\mathrm{ab}}$ & Green semi-friable callus \\
\hline \multirow[t]{3}{*}{ 6-furfurylaminopurine+BAP } & $0.5+1.0$ & 20 & $12.66 \pm 2.08^{\mathrm{b}}$ & Creamish compact callus \\
\hline & $0.5+2.0$ & 20 & $13.66 \pm 2.51^{\mathrm{ab}}$ & Creamish compact callus \\
\hline & $0.5+3.0$ & 20 & $17.33 \pm 1.15^{\mathrm{e}}$ & Creamish compact callus \\
\hline \multirow{2}{*}{ 2, 4-dichlorophenoxyacetic acid+NAA } & $0.5+1.0$ & 20 & $14.33 \pm 1.52^{\mathrm{bcd}}$ & Yellowish friable callus \\
\hline & $0.5+2.0$ & 20 & $16.20 \pm 1.70^{\text {cde }}$ & Yellowish friable callus \\
\hline
\end{tabular}

Values represent the Mean \pm SD in triplicates. One-way analysis of variance followed by Duncan's multiple range tests using SPSS software. p $<0.05$ was considered

statistically significant. BAP: 6-benzylaminopurine, NAA: 1-naphthaleneacetic acid 
$+0.053) \mathrm{r}^{2}=0.9978$. The methanolic root extract $(4.49 \pm 0.18 \mathrm{mg} / \mathrm{g})$ demonstrated higher phenolic content followed by aqueous leaf extract $(4.17 \pm 0.02 \mathrm{mg} / \mathrm{g})$. Whereas aqueous and chloroform root extract showed moderate content of total phenol compared to other extracts of B. montanum (Table 2). Studies by Senguttuvan et al. [20] showed that methanolic extract of root and leaf has higher phenolic content compared to other solvent extracts in Hypochaeris radicata. Siddique et al. [21] reported that the methanolic extract of Aegle marmelos leaf exhibited maximum phenolic content compared to the root and stem. Anyasor et al. [22] observed higher total phenolic content in aqueous extract of Costus afer compared to the methanolic extract.

\section{Total flavonoid content}

Flavonoids are the most common group of polyphenolic compounds which provide health benefits through cell signaling pathways and antioxidant effects [23]. They act as chemical messengers, physiological regulators, and cell cycle inhibitors [24]. These metabolites are mostly used in plants to produce yellow and other pigments which play an important role in the colors of plants. In addition, flavonoids are readily ingested by humans and they display anti-inflammatory, antiallergic, and anticancer properties [25]. The results were determined using the linear regression equation $(y=0.047 x+0.0879) r^{2}=0.9939$. The flavonoid content of different extracts was varying widely between 1.22 and $3.94 \mathrm{mg} \mathrm{QE} / \mathrm{g}$. The methanolic extract of leaf recorded maximum flavonoid content $(3.94 \pm 0.07 \mathrm{mg} / \mathrm{g}$ ) followed by aqueous leaf extract

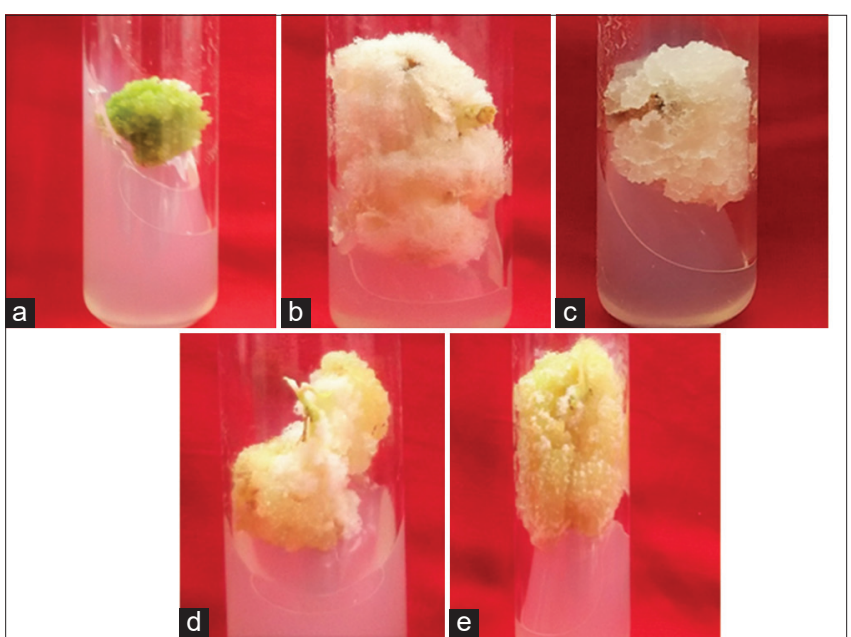

Fig. 1: Effect of different concentrations and combination of auxins and cytokinins on callus induction from stem explants.

a - MS + BAP (0.5 mg/L) + 1-naphthaleneacetic acid (NAA)

$(0.5 \mathrm{mg} / \mathrm{L}), \mathrm{b}$ and $\mathrm{c}-6$-furfurylaminopurine $(0.5 \mathrm{mg} / \mathrm{L})+\mathrm{BAP}$

$(2.0$ and $3.0 \mathrm{mg} / \mathrm{L})$, and $d$ and $\mathrm{e}-2,4$-dichlorophenoxyacetic acid $(0.5 \mathrm{mg} / \mathrm{L})+\mathrm{NAA}(1.0$ and $2.0 \mathrm{mg} / \mathrm{L})$
$(3.18 \pm 0.77 \mathrm{mg} / \mathrm{g})$. Studies by Awah and Verla [26] revealed maximum flavonoids content in the methanolic leaf extract of Ocimum gratissimum compared to other phytochemical constituents. According to Basma et al. [27], the methanolic extract of Euphorbia hirta leaves exhibited a significant amount of flavonoid content followed by the flowers, roots, and stem, respectively. Ruwali et al. [28] also reported that methanolic extract of Michelia champaca leaf exhibited higher flavonoid content compared to other solvent extracts.

\section{Total tannin content}

Tannins are heterogeneous class of phenolic polymers in the 50030,000 molecular weight which are water soluble and are capable of precipitating soluble proteins from solution. These compounds have been proposed as an important component of plant chemical defenses against herbivorous animals, fungi, and microbes [29]. In our present study, methanolic extract $B$. montanum leaf extract possessed high tannin content compared to other extracts $(6.95 \pm 0.38 \mathrm{mg} / \mathrm{g})$. Total tannin content was calculated using standard curve of catechin $(y=0.0073 x+0.0236) r^{2}=0.995$. The methanolic extract of leaf showed maximum tannin content $(6.95 \pm 0.38 \mathrm{mg} / \mathrm{g})$ followed by root extract $(6.66 \pm 0.06 \mathrm{mg} / \mathrm{g})$. Whereas aqueous and chloroform extract of leaf showed moderate tannin content compared to other extracts of B. montanum. Studies by Rajesh et al. [30] reported that methanolic leaf extract of Terminalia catappa showed maximum tannin content compared to other extracts. According to Kassim et al. [31], the ethyl acetate and methanolic extracts of Uncaria gambir recorded higher tannin content compared to aqueous extract. Ashwini and Majumdar [32] reported that methanolic root extract showed maximum content of tannin compared to other solvent extracts in Exacum bicolor.

\section{DPPH radical scavenging assay}

Fig. 2 shows the dose-response curve of DPPH radial scavenging activity compared with standard BHT. In the present study, methanolic extract of leaf and root showed significant scavenging activity with an $\mathrm{IC}_{50}$ value around $80.0 \mu \mathrm{g} / \mathrm{ml}$ compared to other extracts. According to Adebiyi et al. [5], ethanolic extract of Grewia carpinifolia leaf revealed the highest scavenging activity compared to other extracts. Basma et al. [27] showed that methanolic extract of E. hirta leaves exhibited a maximum dose-dependent DPPH scavenging activity followed by the flowers, roots, and stem, respectively.

\section{Reducing power assay}

The reducing power assay evaluates the ability of plant fractions to reduce $\mathrm{Fe}^{3+}$ ions to $\mathrm{Fe}^{2+}$ by electron donation. This was facilitated by the presence of potassium ferricyanide ( $\mathrm{K} 3[\mathrm{Fe}(\mathrm{CN}) 6])$ [33]. In this assay, the yellow color of the test solution changes to various shades of green and blue, depending on the reducing power of each compound. The presence of reducers causes the reduction of the $\mathrm{Fe}^{2+}$ to the ferrous forms. Therefore, by measuring the formation at $700 \mathrm{~nm}$, we can monitor the $\mathrm{Fe}^{2+}$ concentration [34]. The reducing power ability of methanolic extracts of leaf, stem, root, and stem-derived callus showed dose-dependent

Table 2: Total phenolics, flavonoids, and tannin content of different extracts of Baliospermum montanum

\begin{tabular}{|c|c|c|c|c|}
\hline Plant samples & Solvents (mg/g) & Total phenolics (mg GAE/g) & Total flavonoids (mg QE/g) & Total tannins (mg CE/g) \\
\hline \multirow[t]{3}{*}{ Leaf } & Methanol & $3.22 \pm 0.04^{\mathrm{d}}$ & $3.94 \pm 0.07^{\mathrm{e}}$ & $6.95 \pm 0.38^{d}$ \\
\hline & Aqueous & $4.17 \pm 0.02^{\mathrm{e}}$ & $3.18 \pm 0.77^{\mathrm{d}}$ & $6.25 \pm 1.89^{c}$ \\
\hline & Chloroform & $0.04 \pm 0.06^{\mathrm{a}}$ & $1.89 \pm 0.35^{\mathrm{d}}$ & $5.65 \pm 0.27^{c}$ \\
\hline \multirow[t]{3}{*}{ Stem } & Methanol & $3.13 \pm 0.10^{\mathrm{d}}$ & $2.17 \pm 0.03^{c}$ & $3.77 \pm 0.51^{\mathrm{ab}}$ \\
\hline & Aqueous & $2.30 \pm 0.13^{\mathrm{b}}$ & $2.00 \pm 0.04^{\mathrm{b}}$ & $3.34 \pm 0.11^{\mathrm{b}}$ \\
\hline & Chloroform & $0.31 \pm 0.08^{\mathrm{b}}$ & $1.52 \pm 0.10^{\mathrm{d}}$ & $2.67 \pm 0.32^{\mathrm{d}}$ \\
\hline \multirow[t]{2}{*}{ Root } & Methanol & $4.49 \pm 0.18^{g}$ & $2.11 \pm 0.20^{\mathrm{bc}}$ & $6.66 \pm 0.06^{d}$ \\
\hline & Chloroform & $3.66 \pm 0.23^{d}$ & $1.22 \pm 0.03^{\mathrm{b}}$ & $1.99 \pm 0.12^{b}$ \\
\hline \multirow[t]{3}{*}{ Stem callus } & Methanol & $1.82 \pm 0.05^{\mathrm{a}}$ & $1.42 \pm 0.03^{\mathrm{a}}$ & $1.61 \pm 0.24^{\mathrm{e}}$ \\
\hline & Aqueous & $2.05 \pm 0.03^{\mathrm{a}}$ & $2.21 \pm 0.01^{\mathrm{cd}}$ & $1.39 \pm 0.76^{\mathrm{d}}$ \\
\hline & Chloroform & $0.48 \pm 0.01^{\mathrm{a}}$ & $1.28 \pm 0.02^{\mathrm{b}}$ & $1.16 \pm 0.27^{\mathrm{e}}$ \\
\hline
\end{tabular}

Values represent the Mean \pm SD in triplicates. One-way analysis of variance followed by Duncan's multiple range tests using SPSS software. $p<0.05$ was considered statistically significant. GAE: Gallic acid equivalent 


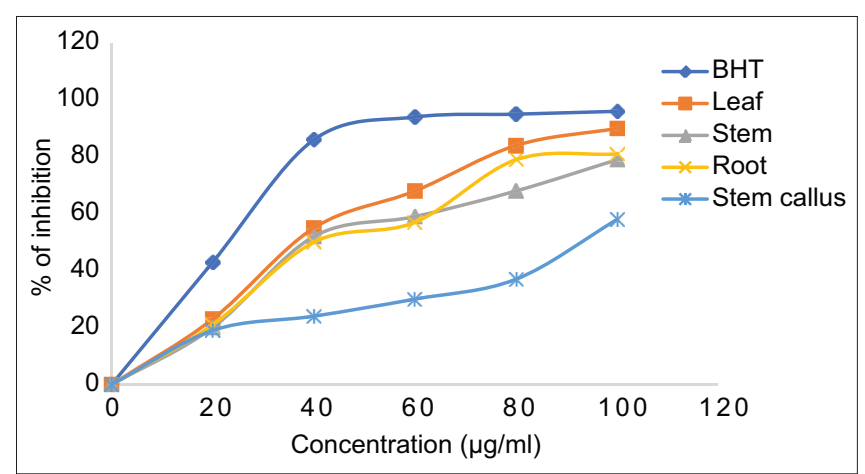

Fig. 2: 2, 2-diphenyl-l-picrylhydrazyl scavenging activity of methanolic extract of Baliospermum montanum

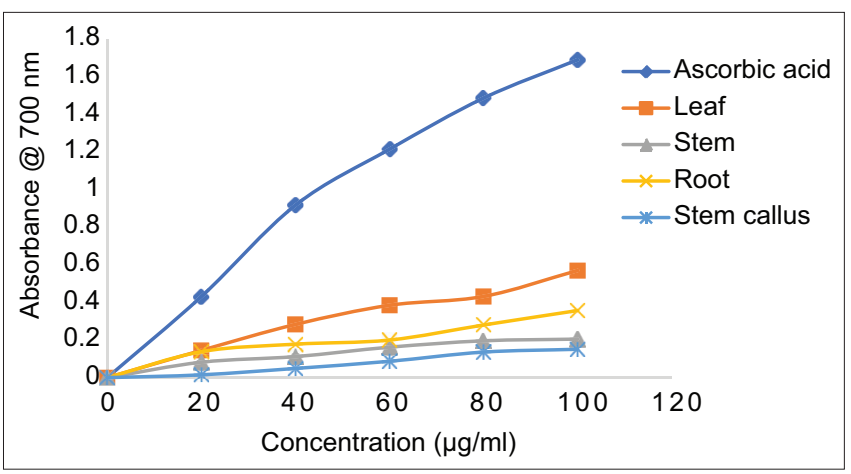

Fig. 3: Reducing power activity of methanolic extract of Baliospermum montanum

relationship as represented in Fig. 3. The leaf extract exhibited higher reducing power activity, whereas methanolic extract of root recorded moderated level of reducing power compared to other extracts. Simur [35] reported that the antioxidant activity was higher in methanolic extract of leaf in Withania somnifera compared to other extracts.

\section{CONCLUSION}

In the present investigation, leaf extract of $B$. montanum exhibited higher phenolic, flavonoid, and tannin content compared to other extracts. The DPPH and reducing power activity were found to be higher in methanolic leaf and root extract which can correlate to higher scavenging activity. Further investigations are required to identify their active metabolites and antiproliferation activity.

\section{ACKNOWLEDGMENT}

The authors are thankful to the Department of Botany, Bangalore University, Bengaluru.

\section{AUTHORS' CONTRIBUTIONS}

Sushma has done a phytochemical and antioxidant activity. Raveesha coordinated the work and writing of the manuscript.

\section{COMPETING INTEREST}

The authors declared that they have no conflicts of interest.

\section{REFERENCES}

1. Ranilla LG, Kwon YI, Apostolidis E, Shetty K. Phenolic compounds, antioxidant activity and in vitro inhibitory potential against key enzymes relevant for hyperglycemia and hypertension of commonly used medicinal plants, herbs and spices in Latin America. Bioresour Technol 2010;101:4676-89.

2. Amabye TG, Shalkh TM. Phytochemical screening and evaluation of antibacterial activity of Ruta graveolens L. A medicinal plant grown around Mekelle, Tigray, Ethiopia. Nat Prod Chem Res 2015;3:1-4.

3. Benabdallah A, Rahmoune C, Boumendjel, Aissi O, Messaoud C. Total phenolic content and antioxidant activity of six wild Mentha species. Asian Pac J Trop Biomed 2016;6:760-6.

4. Sahoo S, Ghosh G, Das D, Nayak S. Phytochemical investigation and in vitro antioxidant activity of an indigenous medicinal plant Alpinia nigra B.L. Burtt. J Trop Biomed 2013;3:871-6.

5. Adebiyi OE, Olayemi FO, Ning-Hua T, Guang-Zhi Z. In vitro antioxidant activity, total phenolic and flavonoid contents of ethanol extract of stem and leaf of Grewia carpinifolia. J Basic Appl Sci 2017;6:10-4.

6. Paqua G, Pinorosa A, Monacelli B, Santamaria AR, Argentieri MP. Metabolites in cell suspension cultures, calli and in vitro regenerated organs of Hypericum perforatum cv. Topas. Plant Sci 2003;165:977-82.

7. Sharma PC, Yelne MB, Dennis TJ. Database on Medicinal Plants Used in Ayurveda. Vol. 1. New Delhi: Central Council for Research in Ayurveda and Sidda; 2000. p. 114-7.

8. Sivarajan VV, Balachandran I. Ayurveda Drugs and Plant Sources. New Delhi: Oxford and IBH Publishing Co. Pvt. Ltd.; 1994. p. 125-6.

9. Samydurai P, Saradha M. Effects of various solvent on the extraction of antimicrobial, antioxidant, phenolic from the stem bark of Decalepis hamiltonii Wight and Arn. Asian J Res Pharm Sci 2016;6:129-33.

10. Singleton VL, Orthofer R, Lamuela-raventos RM. Analysis of total phenols and other oxidation substrates and antioxidants by means of folin-ciocalteu reagent. Methods Enzymol 1999;299:152-78.

11. Rajendran C, Christopher FC, Ramu N, Pazhamalai V, Mohankumar N, Ethiraj S. Studies on phytochemical screening, antioxidant activity and extraction of active compound (2-hydroxy 4-methoxy benzaldehyde) from rhizome extract of Decalepis hamiltonii Wight and Arn. Int J Curr Biotechnol 2014;2:31-9.

12. Medini F, Fellah H, Ksouri R, Abdelly C. Total phenolic, flavonoid and tannin contents and antioxidant and antimicrobial activities of organic extracts of shoots of the plant Limonium delicatulum. J Taibah Univ Sci 2014;8:216-24.

13. Shoib AB, Shahid AM. Determination of total phenolic and flavonoid content, antimicrobial and antioxidant activity of a root extract of Arisaema jacquemontii. J Taibah Univ Sci 2015;9:449-54

14. Kuda T, Tsunekawa M, Hishi T, Araki Y. Antioxidant properties of dried 'kayamo-nori', a brown alga Scytosiphon lomentaria (Scytosiphonales, Phaeophyceae). Food Chem 2005;89:617-22

15. Elangomathavan R, Kalaivanan P, Hariharan P, Beaulah SN. High efficient protocol for callus induction and regeneration of a medicinal plant Orthosiphon stamineus. Int J Adv Res Biol Sci 2017;4:113-22.

16. Nathar VN, Yatoo GM. Micropropagation of an antidiabetic medicinal plant Artemisia pallens. Turk J Bot 2014;38:491-8.

17. Tepe B, Sokmen M, Akpulat HA, Sokmen A. Screening of the antioxidant potentials of six Salvia species from Turkey. Food Chem 2006;95:200-4.

18. Olas B, Wachowicz B. Resveratrol, a phenolic antioxidant with effects on blood platelet functions. Platelets 2005;16:251-60.

19. Ferdous M, Basher MA, Khan I, Ahmed F, Sobuz SI, Daula AF. Evaluation of phytochemicals, antioxidant and antibacterial potentials of Alpinia calcarata. J Med Plants Stud 2018;6:152-8.

20. Senguttuvan J, Paulsamy S, Karthika K. Phytochemical analysis and evaluation of leaf and root parts of the medicinal herb, Hypochaeris radicata $\mathrm{L}$. For in vitro antioxidant activities. Asian Pac J Trop Biomed 2014;4:S359-67

21. Siddique NA, Mujeeb M, Najmi AK, Akram M. Evaluation of antioxidant activity, quantitative estimation of phenols and flavonoids in different parts of Aegle marmelos. Afr J Plant Sci 2010;4:1-5.

22. Anyasor GN, Ogunwenmo O, Oyelana OA, Akpofunure BE. Phytochemical constituents and antioxidant activities of aqueous and methanol stem extracts of Costus afer Ker Gawl. (Costaceae). Afr J Biotechnol 2010;9:4880-4.

23. Havsteen BH. The biochemistry and medical significance of the flavonoids. Pharmacol Ther 2002:96:67-202

24. Cicerale S, Lucas L, Keast R. Biological activities of phenolic compounds present in virgin olive oil. Int J Mol Sci 2010;11:458-79.

25. Crozier A, Ashihara H. In: Clifford MN, editor. Plant Secondary Metabolites and the Human Diet. Oxford. England: Blackwell Publishing; 2006.

26. Awah FM, Verla AW. Antioxidant activity, nitric oxide scavenging activity and phenolic contents of Ocimum gratissimum leaf extract. J Med Plants Res 2010;4:2479-87.

27. Basma AA, Zakaria Z, Latha LY, Sasidharan S. Antioxidant activity and phytochemical screening of the methanol extracts of Euphorbia hirta L. Asian Pac J Trop Med 2011;4:386-90. 
28. Ruwali P, Adhikari M, Sharma S. Phytochemical and antioxidant properties of various extracts of Michelia champaca leaves. Int J Pharm Pharm Sci 2019;11:56-61.

29. Wisdom CS, Gonzalez-Coloma A, Rundel PW. Ecological tannin assays: Evaluation of proanthocyanidins, protein binding assays and protein precipitating potential. Oecologia 1987;72:395-401.

30. Rajesh BR, Potty VP, Sreelekshmy SG. Study of total phenol, flavonoids, tannin contents and phytochemical screening of various crude extracts of Terminalia catappa leaf, stem bark and fruit. Int $\mathrm{J}$ Appl Pure Sci Agric 2016;2:291-6.

31. Kassim MJ, Hussin MH, Achmad A, Dahon NH, Suan TK, Hamdan HS. Determination of total phenol, condensed tannin and flavonoid contents and antioxidant activity of Uncaria gambir extracts. Majalah Farmasi
Indonesia 2011;22:50-9.

32. Ashwini AM, Majumdar M. Quantification of phytochemical contents and in vitro antioxidant activity of Exacum bicolor (Roxb.), an endemic medicinal plant. Int J Pharm Pharm Sci 2015;7:225-30.

33. Olivier MT, Muganza FM, Shai LJ, Gololo SS, Nemutavhanani LD: Phytochemical screening, antioxidant and antibacterial activities of ethanol extracts of Asparagus suaveolens aerial parts. South Afr J Bot 2017;108:41-6.

34. Milady S, Damak M. In vitro antioxidant activities of Aloe vera leaf skin extracts. J Soc Chimique Tunisie 2008;10:101-9.

35. Simur TT. Phytochemical investigation and antioxidant activity of leaf extract of Withania somnifera from Konso, South Ethiopia. Orient J Chem 2018;34:1824-31. 